DOI http://dx.doi.org/10.18551/rjoas.2016-08.17

\title{
VOLATILITY OF SORGHUM PRODUCTION UNDER RAINFALL SYSTEM IN GADARIF STATE, SUDAN
}

\author{
Elkhatim Asma Khalifa \\ University of Khartoum, Sudan \\ E-mail: asmakhalifa85@yahoo.com
}

\begin{abstract}
This paper aimed at analyzing the impact of the likely changes in rainfall on sorghum production under rain-fed mechanized farming system in Gadarif State of the Sudan. The study used monthly rainfall data for the period 1941-2014 and sorghum area, production and yield for the period 1970-2014. The data were analyzed by simple statistical and econometric regression methods. Generally, rainfall in Gadarif starts in May and ends by mid-October. The number of rainy days and volume $(\mathrm{mm})$ of rain tended to decrease in June and peak up in July and August. The results indicated an increasing trend of rainfall mostly fallen during July and August during 1941-2014. The results also showed that dry rainfall years affected the productivity of sorghum reducing it by $4.9 \mathrm{~kg} / \mathrm{feddan} / \mathrm{year}$ and that floody rainfall years led to the decrease in the productivity by $11.3 \mathrm{~kg} /$ feddan/year, while it was decreasing by 3.39 $\mathrm{kg} / \mathrm{feddan} / \mathrm{year}$ in normal rainfall years. The study found a negative relationship between annual rainfall and crop production. Based on the results obtained, this study recommended concluded that identifying and implementing appropriate adaptation techniques to cope effects with the expected rainfall changes in the future.
\end{abstract}

\section{KEY WORDS}

Staple food, econometric regression, drought, floods, meteorological July, august, consumption.

It is becoming ever more apparent in the scientific research that higher temperatures and changing precipitation levels due to climate change will depress crop yields in many countries. Throughout the coming decades (Yesuf et al 2008). According to projections by the Intergovernmental Panel on Climate Change (IPCC, 2007), rainfall variability and extreme climatic events such as droughts are expected to adversely affect agricultural production and food security (Christiansen et al 2007), with Boko et al (2007) predicting that yields from Africa's rain fed farm production could decrease $50 \%$ by the year 2020 as a result.

Although shifts in rainfall and weather patterns are occurring worldwide, (Barrios et al 2008) found that agricultural production in Sub-Saharan Africa is, relative to other developing countries, particularly sensitive to weather variability as the availability of water differs widely throughout the geographically diverse continent.

Rainfall in Sudan is characterized by short stormy and unreliable seasons (Yousif et al 2009). Moreover, the Sudan has been subjected to cyclical droughts and floods during the period 1970-2014. Most of the drought periods occurred during 1967-1973, 1980-1984, 1987, 1989, 1990-1991, 1993 and 2000. Accordingly, the fluctuation and distribution of rainfall during the season directly together with the droughts and floods incidents, are expected to affect the production of sorghum and subsequently the food security situation in the country (National Drought Mitigation Centre, 2010).

Sorghum is the main staple food crop in Sudan accounting to $65 \%$ of the total consumption of cereals in Sudan (Osman, 1996). It is also an important food crop in many African and Asian countries. In the USA most of the sorghum grain is used as livestock feed. There is, nonetheless, a potential export market for sorghum as food and feed. For food use, the grain is roughly grounded and made into bread-like flakes or loafs. Sometimes sorghum is mixed with wheat flour for bread making. The grain is also a source of native beers, particularly in Africa (Smith, 1990). 
Almost $92 \%$ of the total grown sorghum in the Sudan takes place under the mechanized and the traditional rain-fed production sectors (ARC, 2012). In other hand, (Mohamed, 2011) studied the impact of weather change on Sudanese cereal grains and cash crops such as sorghum and sesame reported a higher impact of rain on yields compared to increased temperatures (Figure 1).

Gadarif State is the major sorghum producing area under rainfall in the country. The state produces $40 \%$ of the sorghum in seven million feddans (Ministry of Agricultural and Foresty, Gadarif Stat, 2014).

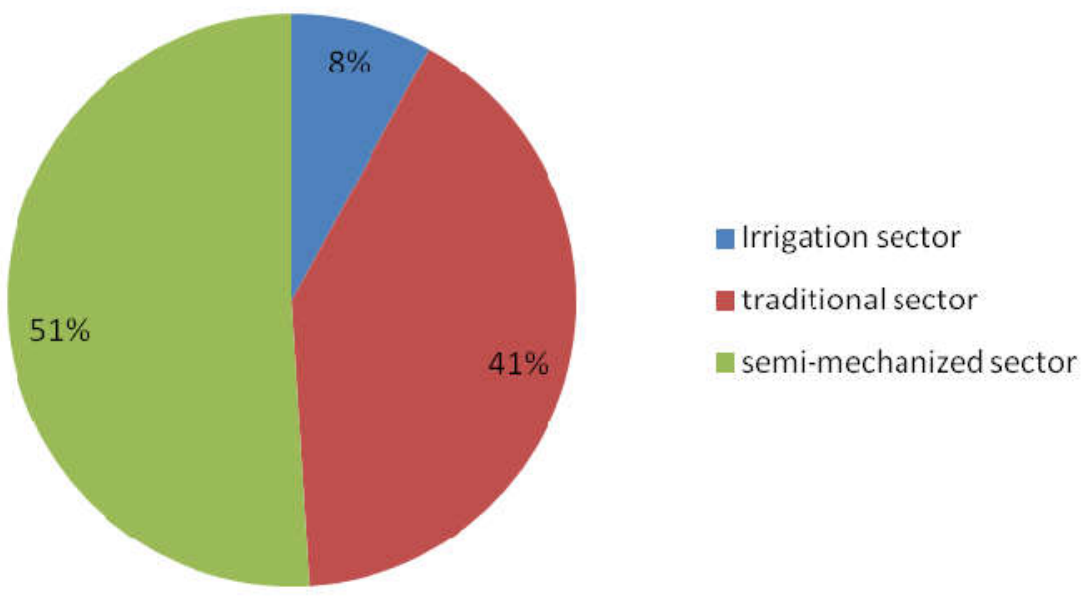

Figure 1 - The average share of irrigated and rainfed farming systems of sorghum harvested area in Sudan during 1990-2012. Source: Ministry of Agriculture and Foresty (Agri, Statistics Department)

Accordingly to FAO (2011), this unreliable rain-fed agriculture system constitutes the basic source and threat for the food security of 8.8 million people, about $22 \%$ the total population of Sudan.

\section{MATERIALS AND METHOD OF RESEARCH}

Multiple regression analysis. Can be multiple regression analysis to test the hypothesis of knowledge of the relationship between the dependent variable and two or more independent variables, the regression analysis is the most commonly used in various fields of science because it describes the relationship between the variables in the form of equations (Gujarati, 1995).

Model can be written as follows:

$$
\begin{gathered}
y_{i}=b_{0}+b_{1} x_{1 i}+\ldots \ldots+b_{k} x_{k i}+e \\
\text { Or } \\
y_{i}=b_{0}+b_{1} x_{1 i}+b_{2} x_{2 i}+u_{i}
\end{gathered}
$$

The study used secondary data of rainfall, sorghum area, yield and production. It also employed the simple statistical and multiple regression methods for data analysis. The multiple regression models are given below.

Sorghum production model for the period 1970-2014:

Where: $\mathrm{Sp}_{\mathrm{t}}$ : dependent variable represents the production of sorghum; $\mathrm{b}_{\mathrm{o}}$ : intercept. 
The independent variables are:

- $\mathrm{rf}_{\mathrm{t}}$ : rainfall in Gadarif State $\mathrm{mm} / \mathrm{yr}$

- harvs $s_{t}$ : harvested area of sorghum in fed/yr

- $y s_{\mathrm{t}}$ : yield by $\mathrm{kg} / \mathrm{fed}$ of sorghum

- $\min _{\mathrm{t}}$ : minimum temperature in Gadarif State $\mathrm{C}^{\%} / \mathrm{yr}$

- $\max _{\mathrm{t}}$ : maximum temperature in Gadarif State $\mathrm{C}^{\circ} / \mathrm{yr}$

- $\operatorname{prs}_{\mathrm{t}}$ : price of sorghum in SDG/kg/yr

- $\mathrm{t}_{\mathrm{t}}$ : time

Sorghum productivity model for the period 1970-2014:

Where: $\mathrm{Sy}_{\mathrm{t}}$ : dependent variable represents the average productivity of sorghum(kglfed); $\mathrm{b}_{0}$ : intercept.

The independent variables are:

- $\mathrm{rf}_{\mathrm{t}}$ : rainfall in Gadarif State $\mathrm{mm} / \mathrm{yr}$

- harvs $s_{t}$ : harvested area of sorghum fed/yr

- Prods $_{\mathrm{t}}$ : production of sorghum ton/yr

- $\min _{\mathrm{t}}$ : minimum temperature in Gadarif State $\mathrm{C}^{\circ} / \mathrm{yr}$

- $\max _{\mathrm{t}}$ : maximum temperature in Gadarif State $\mathrm{C}^{\circ} / \mathrm{yr}$

- $\mathrm{prs}_{\mathrm{t}}$ : price of sorghum in SDG/kg/yr

- $\mathrm{t}_{\mathrm{t}}$ : time

\section{RESULTS OF STUDY}

The performance of rainfall in Gadarif State during 1941-2014. In Gadarif State, the average annual rainfall ranged between $300-900 \mathrm{~mm}$ with a pronounced fluctuating pattern occurring during 1981-2011 (table 1). The trend analysis exhibited cyclical fluctuating rainfall slowly rising in direction during 1941-2014 (Figure 2).

Table 1 - Statistical indicators of average annual rainfall (mm/year) in Gadarif state during 1941-2014

\begin{tabular}{|l|l|l|l|l|l|l|l|l|l|}
\hline Item & $41-50$ & $51-60$ & $61-70$ & $71-80$ & $81-90$ & $91-00$ & $01-10$ & $11-14$ & $41-14$ \\
\hline Average (mm/yr) & 593.4 & 547.5 & 562.4 & 638.4 & 560.2 & 612.5 & 606.2 & 564.9 & 587.4 \\
\hline Std.Dev & 134.3 & 88.4 & 98.2 & 63.2 & 148.8 & 139.2 & 123.3 & 168.6 & 118.1 \\
\hline Coef of variartion (\%) & 22.6 & 16.1 & 17.5 & 9.9 & 26.5 & 22.7 & 20.3 & 29.8 & 20.1 \\
\hline Max (mm/yr) & 863.2 & 697.9 & 751.3 & 774.9 & 758.9 & 870.4 & 910.7 & 807.8 & 910.7 \\
\hline Min (mm/yr) & 418.1 & 377.3 & 417.8 & 549.1 & 322 & 410.1 & 476.5 & 420 & 322 \\
\hline
\end{tabular}

Source: Sudan Meteorological Authority, annual reports.

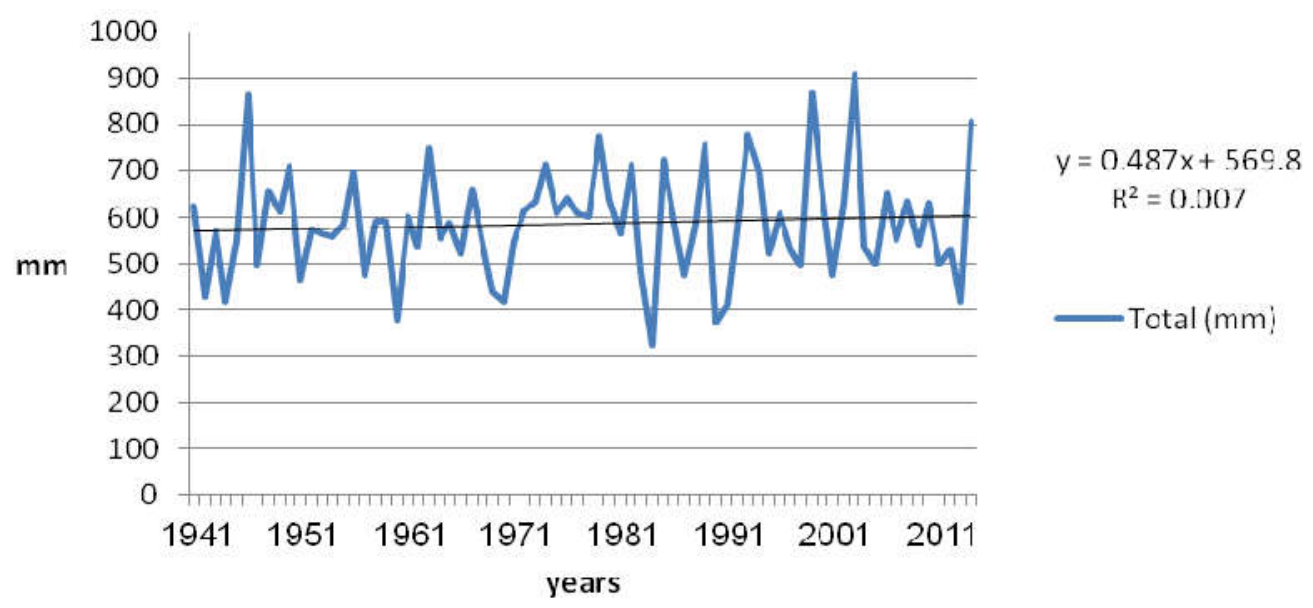

Figure 2 - Performance of rainfall (mm/year) in Gadarif State during 1941-2014. Source: Sudan Meteorological Authority, annual reports. 
Performance of rainy months in Gafarif State during 1941-2014. Rainfall during June months decreased slightly throughout the period of 1941-2014 (figure 3). However, the rainfall rose from a rate of $-0.136 \mathrm{~mm} /$ month in June months to $0.772 \mathrm{~mm} /$ month in July months, a rise of 5.6 folds during the same period (figure 4). On the other hand, rainfall in August months dropped down to $0.211 \mathrm{~mm} / \mathrm{month}$, by about 3.5 times (figure 5). This trend kept falling in September months at rate of $0.109 \mathrm{~mm} / \mathrm{month}$ (figure 6). From this analysis, it may be deducted that crop seasons under rainfed condition in Gadarif State experience short periods of fluctuating amounts and distributions of rainfall, supposedly able to sustain succssful crop production of sorghum crop in the state.

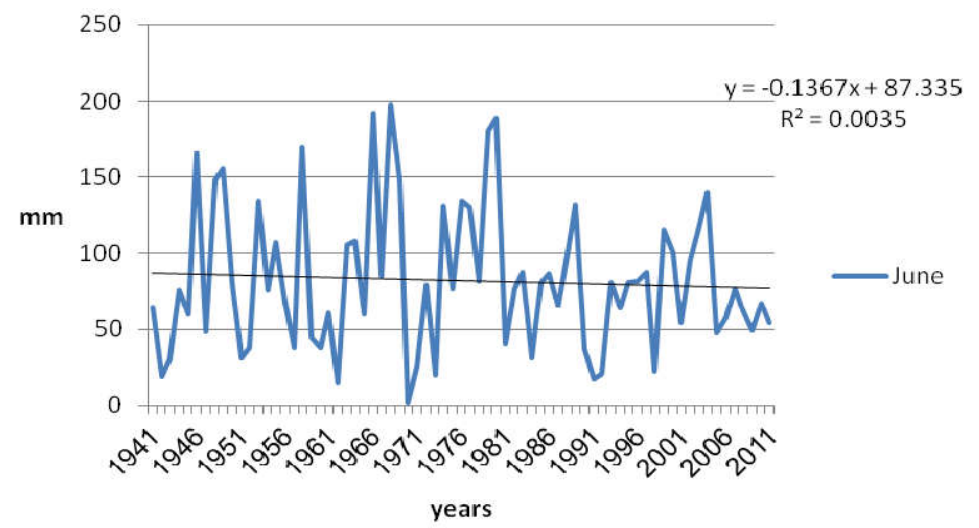

Figure 3 - June months in Gadarif State during 1941-2014. Source: Sudan Meteorological Authority, annual reports.

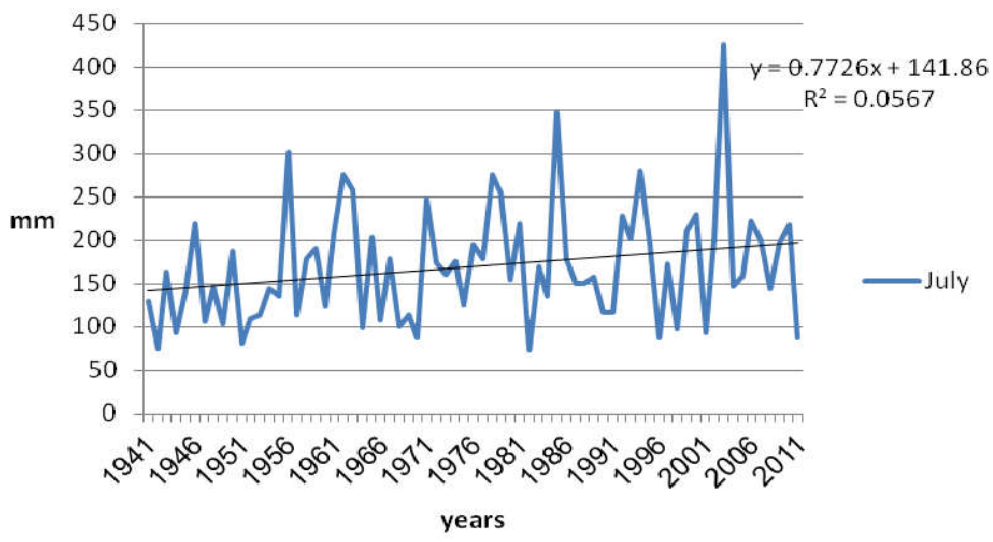

Figure 4 - July months in Gadarif State during 1941-2014. Source: Sudan Meteorological Authority, annual reports.

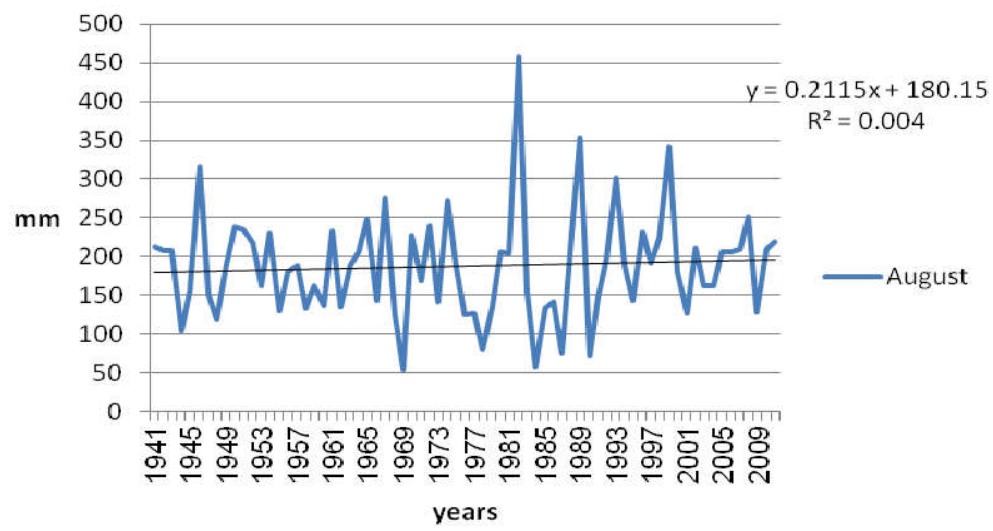

Figure 5 - August months in Gadarif State during 1941- 2014 Source: Sudan Meteorological Authority, annual reports. 


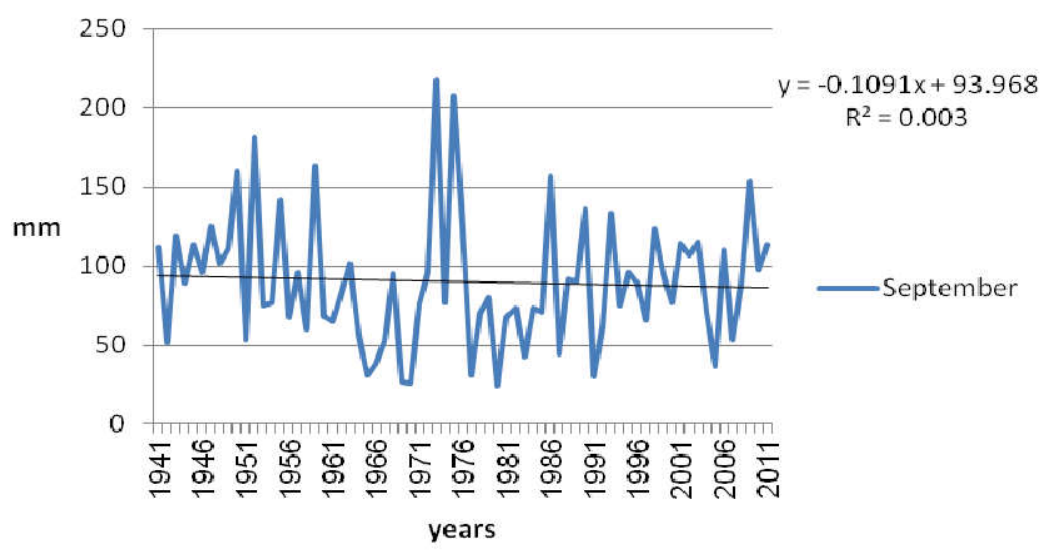

Figure 6 - September months in Gadarif State during 1941- 2014.

Source: Sudan Meteorological Authority, annual reports.

Correlation Analysis Results. The analysis of correlation helps in identifying the possibilty of existance of any relationship between two varaibles. The results of Table (2) showed a weak correlation between rainfall and the sorghum cultivated/harvested area, yield and production. The production and both of the cultivated and harvested area were positively correlated. The sorghum yield had been highly correlated with the harvested area but in a negative direction implying that farmers are obliged continue growing larger areas to compensate for expected drops in their sorghum crop yields.

Table 2 - Correlation between rainfall and production variables in the mechanized farming system in Gadarif State during 1970-2014

\begin{tabular}{|c|c|c|c|c|c|c|c|}
\hline$n / n$ & Item & $\begin{array}{l}\text { Rainfall } \\
(\mathrm{mm})\end{array}$ & $\begin{array}{l}\text { Cultivated area } \\
\text { (000fed) }\end{array}$ & $\begin{array}{l}\text { Production } \\
\text { (000ton) }\end{array}$ & $\begin{array}{l}\text { Harvested area } \\
\quad(000 \mathrm{fed})\end{array}$ & $\begin{array}{c}\text { Yield } \\
\text { (kg/fed) }\end{array}$ & time \\
\hline \multirow{2}{*}{ rainfall } & Pearson Correlation & 1 & .173 & .241 & .210 & -.017 & .049 \\
\hline & Sig. (2-tailed) & & .280 & .128 & .187 & .917 & .762 \\
\hline \multirow{2}{*}{ cultivated } & Pearson Correlation & .173 & 1 & $.805^{m *}$ & $.848^{* *}$ & $-.361^{*}$ & $.636^{\mathrm{xx}}$ \\
\hline & Sig. (2-tailed) & .280 & & .000 & .000 & .020 & .000 \\
\hline \multirow{2}{*}{ production } & Pearson Correlation & .241 & $.805^{* *}$ & 1 & $.749^{* *}$ & .134 & $.331^{*}$ \\
\hline & Sig. (2-tailed) & .128 & .000 & & .000 & .405 & .035 \\
\hline \multirow{2}{*}{ harvested } & Pearson Correlation & .210 & $.848^{\pi *}$ & $.749^{\prime \prime}$ & 1 & $-.486^{\star *}$ & $.439^{* x}$ \\
\hline & Sig. (2-tailed) & .187 & .000 & .000 & & .001 & .004 \\
\hline \multirow{3}{*}{ Yield } & Pearson Correlation & -.017 & $-.361^{*}$ & .134 & $-.486^{\pi \times}$ & 1 & $-.440^{\pi \times}$ \\
\hline & Sig. (2-tailed) & .917 & .020 & .405 & .001 & & .004 \\
\hline & $\begin{array}{c}\text { Number of } \\
\text { observations }\end{array}$ & 44 & 44 & 44 & 44 & 44 & 44 \\
\hline
\end{tabular}

** Correlation is significant at the 0.01 level (2-tailed).

${ }^{*}$ Correlation is significant at the 0.05 level (2-tailed).

Sorghum productivity under normal, dry and wet levels of rainfall. Sorghum productivity trend analysis showed three distinct performances under three levels of rainfall. The relationship between sorghum yield and dry rainfall years indicated a decreasing trend of 4.9 $\mathrm{kg} / \mathrm{fed} / \mathrm{year}$. This effects the considerable negative effect of rainfall quantities and distribution upon sorghum crop yields during dry periods.

The relationship between sorghum yield and normal rainfall had also indicated a drop of $3.39 \mathrm{~kg} / \mathrm{fed} / \mathrm{year}$. The sharp drop in crop yield is even more remarkable during the wet (floody) rainfall seasons. The drop has taken place at a rate of $11.37 \mathrm{~kg} / \mathrm{fed} / \mathrm{year}$. From the overall results, it seems that both the dry and normal rainfall years are considered to be more favorable for the productivity of sorghum crop than the floody rainfall years.

In general, the decline in sorghum crop yield is likely to be influenced by rainfall performances and other factors such as continued mono-cropping, and poor land prepartion. 


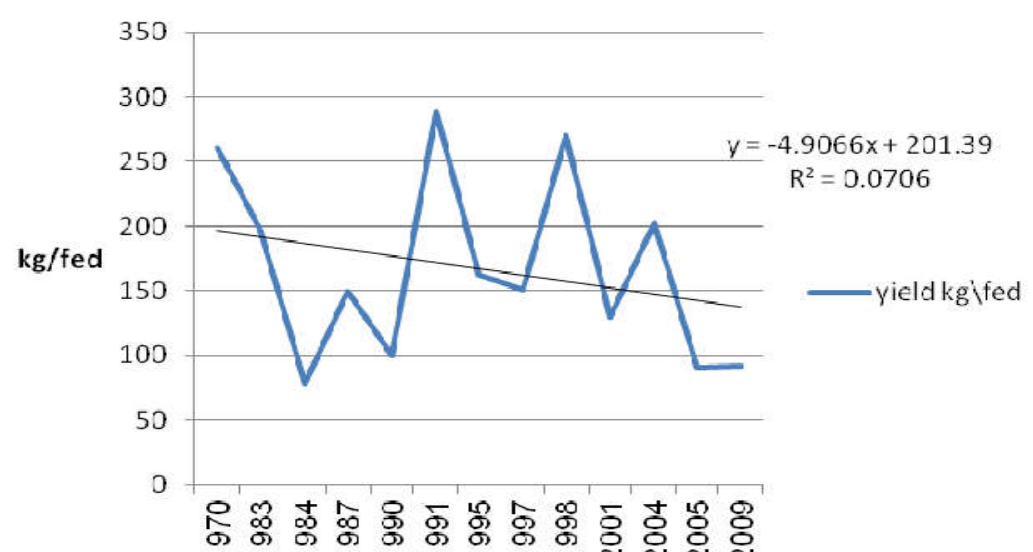

Figure 7 - The performance of sorghum yield in dry rainfall years in Gadarif State during 1970-2014.

Source: Sudan Meteorological Authority and Ministry of agriculture (Gadarif State)

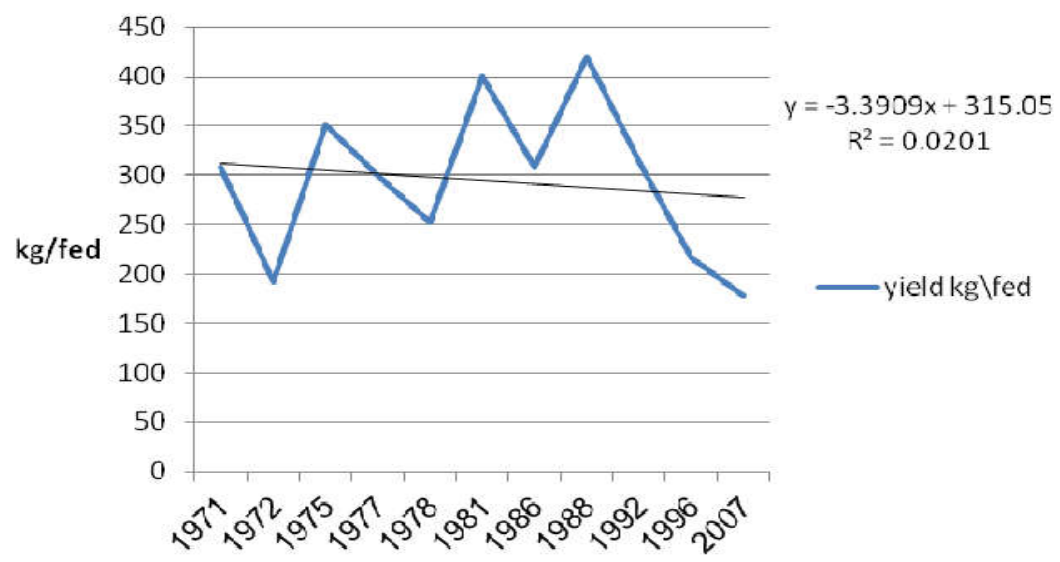

Figure 8 - The performance of sorghum yield in normal rainfall years in Gadarif State during 1970-2014.

Source: Sudan Meteorological Authority and Ministry of agriculture (Gadarif State)

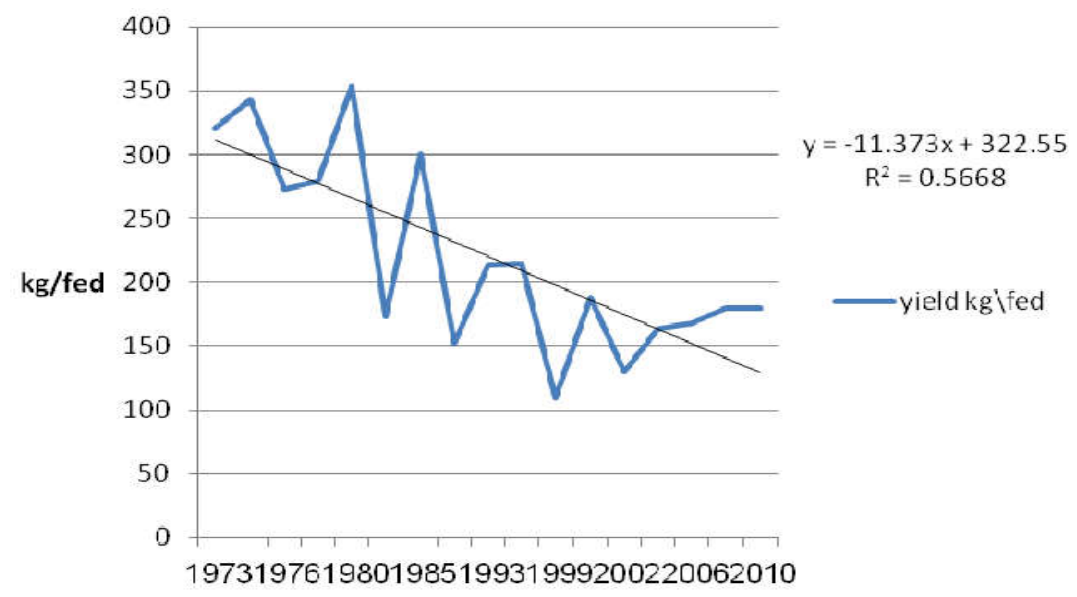

Figure 9 - The performance of sorghum yield in wet rainfall years in Gadarif State during 1970-2014. Source: Sudan Meteorological Authority and Ministry of agriculture (Gadarif State)

Multiple Regression Analysis Results:

Sorghum yield function. The model regressed sorghum yield as a dependant variable against independent variables of time, rainfall, harvested area, price, production, minimum and maximum temperture. Table (3) gives the results with the adjusted $R^{2}$ of $95 \%$ reflecting the extent of the variables captured and explained by the specified model. The $F-$ value statistic of 128 indicated the good overall signifiance of the model. 
Table 3- Regression results of sorghum yield model in Gadarif State during 1970-2014

\begin{tabular}{|l|l|l|l|}
\hline \multicolumn{1}{|c|}{ Variables } & \multicolumn{1}{c|}{ coefficients } & \multicolumn{1}{c|}{ T- value } & significance \\
\hline (Constant) & 583.343 & 2.072 & .046 \\
\hline Time & -1.268 & -1.745 & .090 \\
\hline Rainfall & .056 & 2.181 & .036 \\
\hline Price & .248 & 1.696 & .099 \\
\hline Min-temp & 13.362 & 1.789 & .083 \\
\hline Max-temp & -17.549 & -2.151 & .039 \\
\hline production & .361 & 23.217 & .000 \\
\hline Harvested area & -.086 & -13.779 & .000 \\
\hline
\end{tabular}

Dependent Variable: Sorghum yield

Adjusted $R^{2}=95 \%$

F-value $=128$

The yield of sorghum model was significant with all variables. The relationship was positive between yield of sorghum and rainfall, price, minimum temperature and production. Conversely, the relationship was negative between yield of sorghum and time, maximum temperature and harvested area. As rainfall increased by one $\mathrm{mm} / \mathrm{year}$, there was an associated increase in the yield by $0.056 \mathrm{~kg} / \mathrm{fed}$.

The significant but negative relationship between yield of sorghum and harvested area indicated that an increase of one feddans in harvested area would decrease the sorghum yield by $0.086 \mathrm{~kg} / \mathrm{fed}$. This decrease might be related to the poor availability of soil plant nutrients, and the fluctuating amount and distribution of rainfall.

The significant relationships between sorghum yield and maximum temperature indicates that as the maximum temperature increases by $1^{\circ} \mathrm{C}$ the yield of sorghum would decrease by $17.5 \mathrm{~kg} / \mathrm{fed}$. The combined effects of climate change seemed to have implications for dry land irrigated crop yields, as well as irrigation water use. Rising temperatures cause stress on crops.

Sorghum productin function results. The model of the production of sorghum was formulated by regressing production quantities against rainfall, time, harvested area, price, yield, maximum and minimum tempreature. Table (5) gives the result of the regression analysis for the period (1970-2014). The adjusted $\mathrm{R}^{2} 97 \%$ reflects the capacity of the model in explaining the percentage of the reality modeled. The F-value of 243 indicated the overall signifinace of the model.

Table 4 - Regression results of sorghum production model in Gadarif State during 1970-2014

\begin{tabular}{|l|l|l|l|}
\hline \multicolumn{1}{|c|}{ Variables } & \multicolumn{1}{c|}{ coefficients } & \multicolumn{1}{c|}{ T- value } & \multicolumn{1}{c|}{ significance } \\
\hline Constant & -1361.090 & -1.771 & .086 \\
\hline Time & 3.002 & 1.522 & .137 \\
\hline Max-temp & 43.400 & 1.958 & .058 \\
\hline Min-temp & -38.003 & -1.903 & .066 \\
\hline Yield & 2.607 & 23.217 & .000 \\
\hline Rainfall & -.157 & -2.269 & .030 \\
\hline Price & -.719 & -1.844 & .074 \\
\hline Harvested area & .241 & 21.433 & .000 \\
\hline
\end{tabular}

Dependent Variable: Sorghum production

Adjusted $R^{2}=97 \%$

F-value $=$ highly significant (243)

From the results, all the variables were significant expect in the case of time. Rainfall was significant and had negative relationship with sorghum production. As rainfall increased by one $\mathrm{mm} /$ year, there would be an associated decrease in the production by 0.15 ton, probably due to variation of rainfall, leading to the risk of water lodging and floods. Changes in the seasonal distribution and with poor rainfall would affect the growth of the sorghum crop. The results also showed that harvested area and yield were significant and had positive effects. As harvested area increased by one feddans, the production of sorghum would increase by 0.24 ton, and as yield increased by $1 \mathrm{~kg} / \mathrm{fed}$ would increase production by 2.6 
tons. The relationship between sorghum production and each of the maximum and minimum temperatures were significant, but positive in case of the former and negative in the case of later. This is likely to increase the evaporation rates of rising temperatures and declining soil moisture contents.

\section{CONCLUSION}

Climate change and variability phenomena under investigation in Sudan indicated that rainfall has been moving southwards, with recurrent droughts and flooding cycles (UNFCCC,2007). The data analysis in Gadarif State showed that crop seasons under rainfed condition experienced short periods of fluctuating amounts and distributions of rainfall. Still, they were able to sustain sorghum crop production in the state. The volatility in climate change variables, namely rainfall and temperature, compelled crop producers to expand land area to compensate for fluctuations in sorghum yields.

Consequently, the negative relationship between rainfall and production of sorghum in Gadarif State would require the introduction of crop varities that resist drought and floods. This is to be supported by the introduction of water harvesting system to supplement crops with irrigation water during drought periods. Moreover, a good drainage system is recommended to reduce the risk of water logging. Use of meteorology information for early prediction of unexpected events of rainfall variability is recommended.

\section{REFERENCES}

1. Agricultural Research Corporation (ARC). (2012). Annual report.

2. Food and Agriculture Organization (FAO). (2011). Statisic report.

3. Intergovernmental Panel on Climate Change (IPCC) (2007). FourthAssessment Report, Climate change-the physical science basis, Chapter 2 Changes in atmospheric constituents and radiative forcing, p. 208.

4. L. Christiaensen, V. Hoffman and A. Sarris.Gauging the welfare effects of shocks in rural tanzania. PolicyResearch Working Paper Series 4406, The World Bank, 2007.

5. M. Boko, I. Niang, A. Nyong, C. Vogel, A. Githeko, M. Medany, B. Osman-Elasha, R. Tabo and P. Yanda. Impacts, Adaptation and Vulnerability. Fourth Assessment Report of the Intergovernmental Panel on Climate Change, 433-467, 2007.

6. Ministry of Agricultural and Foresty. Department of Agriculture Economics. (2014). Year Book of Statistics, Gadarif State.

7. Mohamed IAW (2011) Review of the role of agriculture in Sudan economy. Agric Nat Resource Econ J 3 128:19.

8. M. Yesuf,S. Di Falco, T. Deressa,C. Ringerand G. Kohlin. The impact of climate change and adaptation on food production in low-income countries: evidence from Nile basin, Ethiopia. International Food Policy Research Institute Discussion Paper 00828, 2008.

9. National Drought Mitigation Centre (NDMC) (2010). University of Nebraska, Lincoln, USA. 10. N. Gujarati. Basic Econometrics.Third Edition (1995). USA.

11. United Nations Framework Convention on Climate Change (UNFCCC).(2007).Climate change: impacts, vulnerabilities and adoption in developing countries, UN.

12. Osman, K. A. (1996). Forecasting sorghum production in mechanized rainfed sector. M. Sc. Thesis, Department of Agricultural Economics, University of Khartoum.

13. S. Barrios, B. Ouattara and E. Strobl. The impact of climatic change on agricultural production: is it different for Africa? Food Policy, 33:287-298, 2008.

14. Smith, W. (1990).Sorghum Origin, History, Technology and Production. A\&M University, Texas.

15. Yousif, L.A., Elwaleed M.E. and Saeed B.S. (2009). Influenceof tillage methods on soil moisture content and sorghum grainyield in Vertisols of dryland farming Northern Gedarif. J.Sc.Tech, 10(2):60-68. 